\title{
Public Investment in Education and Training in Vietnam
}

\author{
Phung Van Hien ${ }^{1}$ \\ ${ }^{1}$ National Academy of Public Administration (NaPa), Hanoi, Vietnam \\ Correspondence: Phung Van Hien, National Academy of Public Administration (NaPa), 77, Nguyen Chi Thanh, \\ Dong Da district, Hanoi, Vietnam. Tel: 84-0243-773-4062. E-mail: phunghiennapa@gmail.com
}

Received: March 17, 2018

doi:10.5539/ies.v11n7p106
Accepted: April 20, $2018 \quad$ Online Published: June 28, 2018

URL: https://doi.org/10.5539/ies.v11n7p106

\begin{abstract}
Public investment in education and training occupies an important proportion in Vietnam public budget, approximately $20 \%$, equivalent to $5 \%$ GDP. Public investment in education and training has many positive benefits and impact on the economy and society by contributing to economic growth, by improving the national productivity, people's qualification and intellectual level well as reducing unemployment, poverty in a country. On the basis of an empirical analysis in Vietnam, this paper propose several relevant recommendation for Vietnam government to improve the performance of public investment in education and training by making contribution to ensure suitable investment structure as well as uphold important role of education and training to the development of the economy and society.
\end{abstract}

Keywords: public investment, public budget, education, training, Vietnam

\section{Introduction}

In the perspective of knowledge economy, UNESCO stated the important role of education and training by inciting governments to increase public investment in education and training. The public investment in education and training is considered as driver for economy and society development by improving people's qualification, intellectual level, supplying qualified human resource, contributing to social values, and the economic growth of a country. Education and training allows a country to exploit and uphold competency of their citizens in general and the employees in particular, by improving working productivity and competence (Sianesi \& Van Reenen, 2000).

In Vietnam, the government pays always a particular attention on public investment in education and training since long time ago. There are many investment policies in education and training such as education fee elimination or reduction; expense support to poor students or ethnic students; support to the development of pre-school education; support to the development of education and training of ethnic children in remote areas... However, apart from several achievements, public investment in education and training still exist shortcomings such as unreasonable investment structure in education and training with inequality of investment in different grades. Also, the activity of training was not linked to the target, not basing on output efficiency.

In this context, this paper aims to analyze the public investment in education and training in Vietnam. On the basis of our empirical analysis, we propose recommendations to Vietnam government for a more suitable investment structure as well as for upholding important the important role of education and training to the development of the economy and society.

\section{Theoretical Framework}

\subsection{Investment in Education and Training}

Education is a service. The difference is that the educational qualification of an individual represents the interest of a country to educational investment. Educational development allowed the man to expand his point of view, his knowledge of linguistics, literature, art, music and the world's diversification. Besides, education and training is background for the development of science and technology. Education and training closely link to science and technology, supporting each other and creating fast and sustainable economic growth, coupling with the development of the society. The development of education and training is always an important motivation for industrialization and modernization of a country; a condition to uphold human resource; a basic element for social development, fast and sustainable economic growth. Human resource is resource of people from a country, a territory, a unit of resources, with ability to mobilize and organize to join in the process of economic and social 
development (Sianesi \& Van Reenen, 2000).

Investment in education and training development is motivation for the development of economy and society. According to Becker (2009), investment in education and training is using resources to create new asset for education and training in particular and for the economy in general in order to improve the knowledge and competence of every subject, creating new potential and motivation for social production. Therefore, public investment in education and training is one of the most basic policies of human development investment selected by countries. Public investment in education and training allowed the countries to meet the requirements of integration and development. On the basis of the requirement of educational and training development, the countries would balance the general resources such as human resource, material resource and financial resource to develop and improve the quality of human resource.

\subsection{Benefits of Public Investment in Education and Training}

\section{- Economic growth}

Education officially has cause and effect relationship with economic growth of the countries; that is modern educational expense brings about economic growth in future. According to Sianesi and Van Reenen (2003), ratio of general student entering school $1 \%$ increasing leads to the increase of GDP per capita from $1 \%$ to $3 \%$. In the economic growth model ò Romer (1994), investment in knowledge creates the changes of science and technology; therefore, public investment in education and training is the most important factor to promote economic growth of each country. The increase of human knowledge and competence would lead to the increase of working productivity and then impact to the economic growth (Ganegodage \& Rambaldi, 2011).

Education and training make contribution to economic growth through promoting working productivity of individual by improving his/her competence as well as knowledge accumulation. Human resource is one of input factors of production function: $\mathrm{Q}=\mathrm{f}(\mathrm{K}, \mathrm{L}, \mathrm{T}, \mathrm{R})$, among them: $\mathrm{K}$ : capital; $\mathrm{L}$ : labor; $\mathrm{T}$ : technology; R: resource. Similar to other factor, labor (L) is the factor that directly impacts to the change of quantity $(\mathrm{Q})$. The investment in education and training changes the quality of labor and then changes the quantity $(\mathrm{Q})$. Therefore, if public investment in education and training is suitably implemented, it would positively impact to the process of economic growth of each country (Osberg \& Sharpe, 2002).

\section{- $\quad$ Labor force}

One of the most important roles of education and training is supplying high quality human resource to the economy and society, making contribution the economic development of each country. Thus, public investment in education and training makes contribution to train high competent labor force. Education and training improve the quality of labor force, representing in capital accumulation, increasing income of employees. Also, education and training is an instrument to propagate progressive ideas of previous generation; this is an important background for the development at present and in the future (McCord and Sachs, 2013).

Also, public investment in education and training also has significant effect on the range of human resource and labor market. People who was trained and educated have more chances and better condition to join in better labor market in comparison with people who was not trained or educated. Therefore, the labor market is very big and exciting in the country with developed education and training such as The US, England, France, Japan... In The US labor market, a survey conducted by careerbuilder.com indicated that about 3 million students of college and university in the United State join in labor force, having the best chance to find job in recent 10 years; besides, $3 / 4$ recruiters are recruiting newly-graduated student and $40 \%$ of them would have beginning salary of 50000USD per year. In Japan, there are high demands of labor force such as information technology, engineer, business manager, marketing... Besides, several services also need more employees such as processing industrial goods, consumer product, food and drinks.

\section{- $\underline{\text { Unemployment }}$}

High proportion of unemployment is concerned by many countries and government in the world, especially for countries with large population such as China (12.6\%), Brazil (12.6\%), and Indonesia (5.6\%). Unemployment not only constrains economic development but also causes bad effects on the society such as thief and burglar, drugs using... In addition to bad effects on the economy, unemployment also causes damages of health and spirit of laborer. Unemployment easily leads to disorder of society, even politic fluctuation. One of the main causes for unemployment is low quality of labor force that does not met requirements of recruiters as well as labor market (Sianesi \& Van Reenen, 2003).

Investment in education and training would reduce the ratio of unemployment, improving skills and competency of labor force, and at the same time having more opportunities to find a good job with better working conditions, 
especially investment in education and training at the university and vocational schools. These two educational levels supply student skills and knowledge required by labor market at present (Mc Grath and Akkoojee, 2009). Almost countries regard university education as the target of strategy to develop educational development.

\section{- $\quad \underline{\text { Poverty }}$}

The first goal of the countries, especially underdeveloped ones is reducing proportion of hunger and poverty. Arising from the differential living standard and thought, the people in underdeveloped countries have higher proportion of hunger and poverty than in the areas with developed education and training system. Earnings of poor people mainly come from manual labor, the work therefore is inefficient. It is because of insufficient knowledge and working skill. Education and training bring about knowledge, opinion and skills, improving working productivity of the poor, allowing them to earn more money.

On the other hand, public investment in education and training, vocational education in poorly-educated regions lets the people here improve their knowledge and upgrade their labor productivity, making contribution to meet the basic requirements of their lives. Investment in education and training, vocational education in poor regions or areas are regarded as the key for the people to unlock the knowledge treasure as well as production development potential in their land (McGrath \& Akoojee, 2009).

According to Statistics Institute of the United Nation Education, Science and Culture Organization (UNESCO, 2014), proportion of hunger and poverty in the world can reduce a half or more than a half if all the teenager and youth finish their secondary school. Education and training have direct and indirect effect on economic growth as well as poverty and hunger. Investment in education and training open the chances to approach the skills, having more opportunities to have job with high income, and at the same time help people to avoid the social risks.

\section{- $\underline{\text { Income inequality }}$}

According to Chiswick (1974), countries which invested in education and training have lower Gini-coefficient in comparison with the countries which have not attach special importance to education. Gini-coefficient is caused by the difference of educational qualification and the investment in education and training. The regions having lower Gini-coefficient almost have diploma or graduated labor force. By considering personal income in accordance with years of study, age and experience, Mincer (1974) stated that each year of study improve personal income to approximately $7 \%$. It indicated that educational qualification directly connects to income inequality.

To improve quality of labor force, public investment in education and training makes contribution to create conditions for the people to find and develop their work ability, improving the incomes (Iatagan, 2015). Public investment in education and training make contribution to filling the gap between the wealth and the poor, especially in developing countries such as Vietnam.

\section{- Intellectual level of people}

The Intellectual level of people is decisive factor to the development of a country. Investment in education and training is the best way to improve educational qualification and knowledge of citizens. Education and training make contribution to increase people knowledge in economic area in particular and in other social areas in general (Iatagan, 2015). Quality of public investment in education and training decides the quality of human resource; it increases grey matter in product value structure of labor work. Improving intellectual level of people, nurturing and developing human resource is objective requirements for the development of the economy and society. Thus, public investment in education and training is indispensable activity in the process of improving people knowledge of countries.

\section{Methodology}

Firstly, we made a literature review on public investment in education and training. Then, we collect and analyze information about the current public investment in education and training in Vietnam. In this paper, we use mainly method of collecting and analyzing secondary statistic data, mainly from the Statistical handbooks of Vietnam in the period of 2010-2016. At the same time, we also update the information of economy, society, investment in education and training through newspaper and other media in order to have the best point of view about the investment in education and training in Vietnam. On the other hand, we also collect relevant statistics such as proportion of illiterate, poverty and hunger, economic growth status... in the annual reports of Ministry of Education and Training, General Statistics Office of Vietnam...

Also, we collect primary data by interviewing 11 leaders of several state-owned companies, 8 economic experts about the management of leaders in state-owned companies. Data collected from statistics and interviews is analyzed for giving out specific demonstration for the problem, assisting to find out solutions for shortcomings 
related to leading manners in state-owned companies. The collected data would be arranged in different section. Data from statistics and interview are generalized and analyzed to withdraw research results that will be presented in the next section.

\section{Research Results}

\subsection{Real Situation of Public Investment in Education and Training}

In Vietnam, education and training is regarded as one of the most important policies of the state. This opinion has been presented in documents of the Party since the Central Resolution No.3 (term VII) in 1993. Vietnam Communist Party affirmed: "Science and technology, education and training is one of the most important policies of the state; investing in education and training is investing for the development". To the Central Resolution No.8 (term XI), the Party affirmed once again: "Education and training is one of the most important policies of the state; it is achievement of the Party, of the State and of the People".

Actually, Vietnam is one of the countries which attached special importance to public investment in education and training. This is the area that was given priority by the state to invest large resource in public budget of the country. During the past few years, public investment in education and training promoted economic grow and social development, creating important infrastructure for the development of the country in many fields. According to the statistics of General Statistics Office of Vietnam, proportion of annual budget expense for education and training of Vietnam is approximately $20 \%$, equivalent to $5 \%$ GDP. In comparison with other countries in the region, proportion of public budget expense for education and training of Vietnam is higher, even with more developed countries such as Singapore, Malaysia, Thailand, and South Korea...

According to the result withdrawn from the Program for International Student Assessment (PISA) implemented by Organization for Economic Co-operation and Development (OECD), Vietnam ranked $19^{\text {th }}$ of the top 20 countries in education and training in the world. With this position, Vietnam surpassed the countries with progressive systems of education and training such as Canada (ranked $20^{\text {th }}$ ) and The US (ranked $25^{\text {th }}$ ).

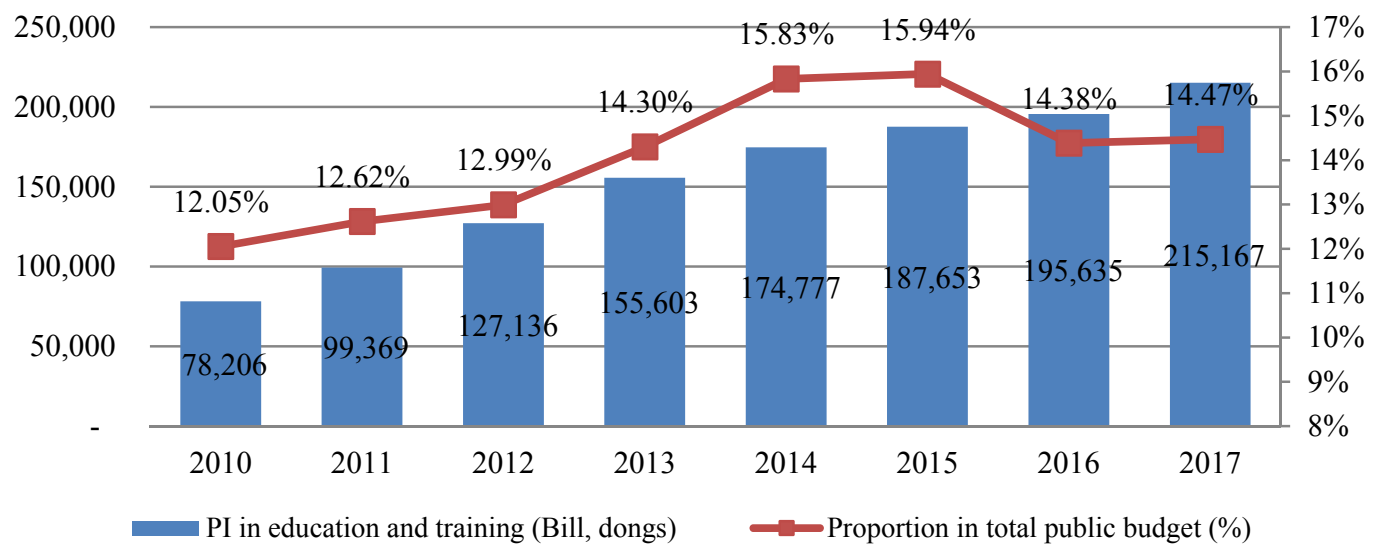

Figure 1, Public investment (PI) in education and training of Vietnam

Source: GOS (2016)

Although the state are implementing policies to tighten budget expense to reduce budget deficit, the state's budget investment in education and training still continually increase in recent years. The investment in education and training was 155,603 billion VND in 2013, 1.5 folded in 2017 and anticipated to continually increase in 2018. It indicated that the state seriously attached special importance to investment in education and training. In 2017, total expense of budget for education and training was 215,167 billion VND, occupying $14.47 \%$ of total expense of budget. To the year 2018, it is estimated that budget expense for investment in education and training is 229,047 billion VND, upgrade the proportion of expense for education and training to $15.04 \%$. The expense will give priority to the building of classroom for pre-school education and primary school to eliminate temporary classroom, building rooms for subjects, laboratory, supporting to build vocational school in local areas.

Besides, the Government also has other support policies such as reducing fee and free of charge; supporting expense for poor students, ethnic students; supporting to develop education and training for ethnic children and in 
remote area; supporting scholarship and educational equipment, school things; implementing policies of education and training for disability... Besides, Vietnam Bank for Social Policies also deployed preferential Credit program for students to create conditions for the poor students to borrow money for studying. To the end of the year 2016 , total loans of the program attained over 56,000 billion VND; outstanding loans attained about 21,000 billion VND with over 3.3 million turns of students who borrows the money to study and to start work.

\subsection{Assessing the Impacts of Public Investment in Education and Training on Vietnam Economy}

\section{- $\quad$ Impact on economic growth}

Public investment in education and training in Vietnam has brought about a great efficiency in the promotion of economic growth. In recent decade, the policies to develop education and training are implemented, continually increasing working productivity, making contribution to make a more wealthy society.

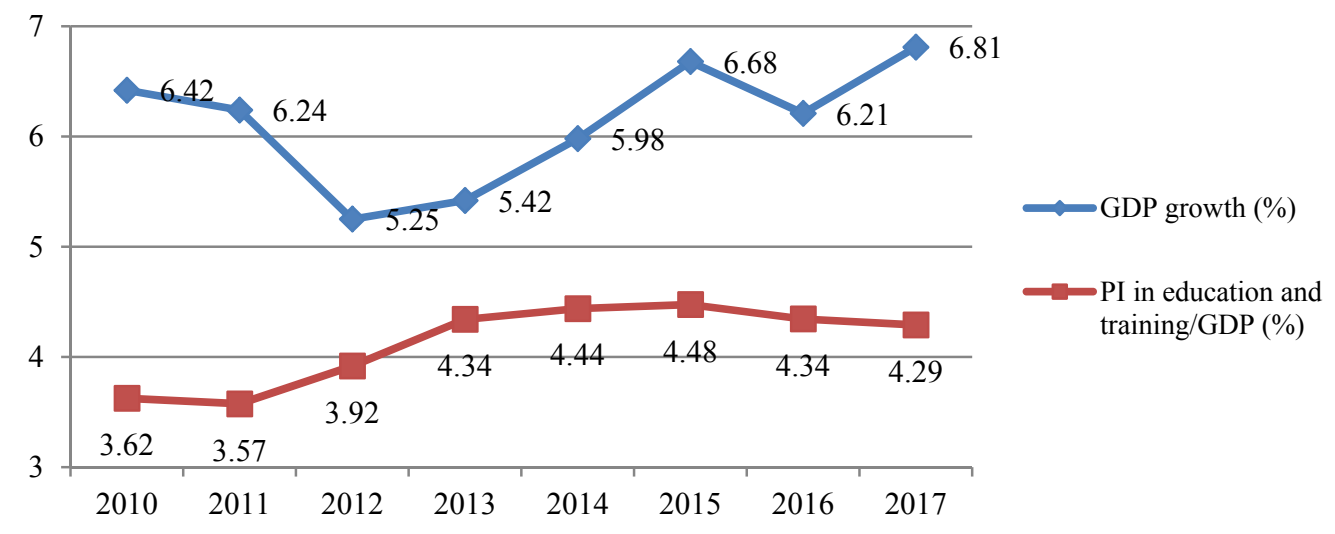

Figure 2. Economic growth and PI in education and training of Vietnam

Source: GOS (2016)

According to the General Statistics Office of Vietnam, economic growth attained 6.81\%, equivalent to 5,008,621 billion GDP in 2017. This was the highest number to the present, marking the turning-point of Vietnam economy. In addition to positive development of economic indicator such as budget over-expenditure, public debt, balance of trade, inflation ratio..., the economy had great improvement in investment efficiency and competitiveness. Although there are fluctuations caused by many factors, GDP tends to increase, representing a developing and growing economy of Vietnam.

The fluctuation of GDP growth is directly proportional to the ratio of public investment in education and training on GDP. The budget expense from 155,603 billion VND from 2013 to 215,167 billion VND in 2017, investment in education and training increased to develop infrastructure, to improve quality of teacher as well as to develop the educational activities, improving quality of young human resource. This allowed the labor force to improve working productivity, creating more products.

\section{- Impact on labor force}

One of present advantages of Vietnam is plentiful human resource. It is because of large and young population, high proportion of population at working age. The annual increase of human resource is bigger than the increase of the population, while the dependent indicator is decreasing. Through investment in education and training, technical proficiency of labor force is improved in quality as well as quantity in recent years. In 2016, proportion of trained over-15-year-old labor force attained 20.6\%, while this proportion in 2015 was 19.9\%. To the year 2017, this proportion attained $31.6 \%$. High proportion of labor force employed in the economy. 


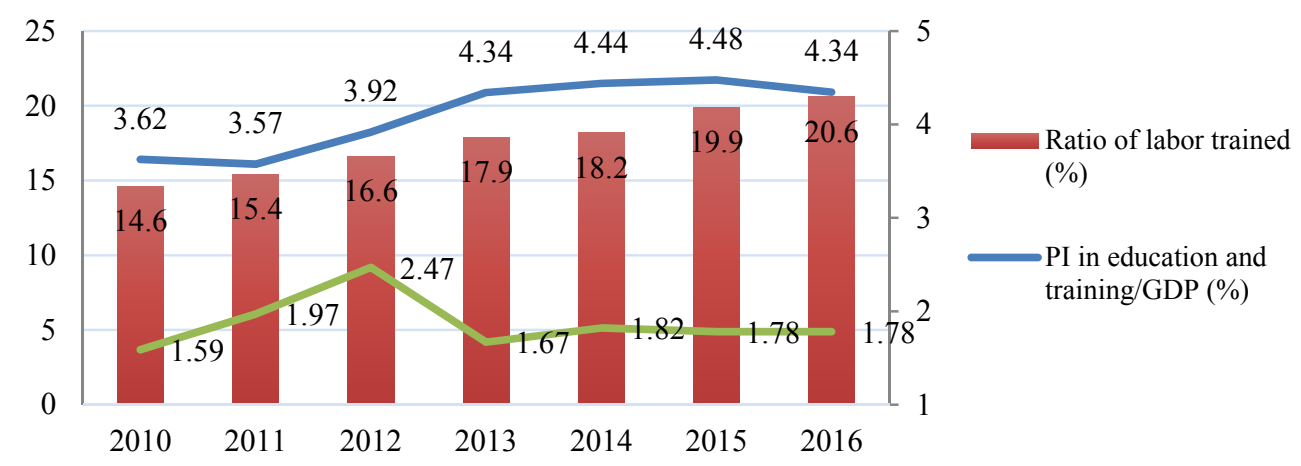

Figure 3: Labor trained and PI in education and training of Vietnam

Source: GOS (2016)

In the period of 2013-2016, trained labor of Vietnam evenly increased, from 9,345,196 in 2013 to 10,980,376 in 2016. Accordingly, ratio of trained labor in working age also significantly increased, from $17.9 \%$ to $20.6 \%$ in four years (from 2013 to 2016). Social labor productivity of the economy in 2016 attained 84.5 million VND per year (equivalent to 3,853 USD per person). In comparison with the year 2010, labor productivity of the economy in 2016 increased 5.31\% in comparison with the year 2015 .

On the contrary, ratio of investment in education and training/labor trained tend to decrease from $18.2 \%$ in 2014 to $17.82 \%$ in 2016 for the rapid growth in quantity of trained labor, especially people graduated from universities and colleges. This indicated that public investment in education and training is more and more efficient for the ratio of trained labor increased while expense is decreasing. However, this ratio still ensure quality of training process for labor force at the moment, if it continue decreasing, the quality of the process will not be guaranteed, that will greatly impact to quantity as well as quality of the human resource in the future.

\section{- Impact on unemployment}

With the increase of public investment in education and training, quality of labor force is improved, therefore, making contribution to reduce ratio of unemployment in Vietnam in recent years. When the public investment in education and training increased, the ratio of unemployment of Vietnam decreased in turn. Specifically, ratio of unemployment in 2016 was $2.30 \%$ ( $3.18 \%$ in urban areas and $1.86 \%$ in rural areas). To the year 2017 , unemployment rate continually decreased in both urban and rural areas. Specifically, in third quarter 2017, there were about 1.11 million unemployed people, decreased 10,900 people in comparison with the second quarter 2017. The national unemployment rate is $2.02 \%$.

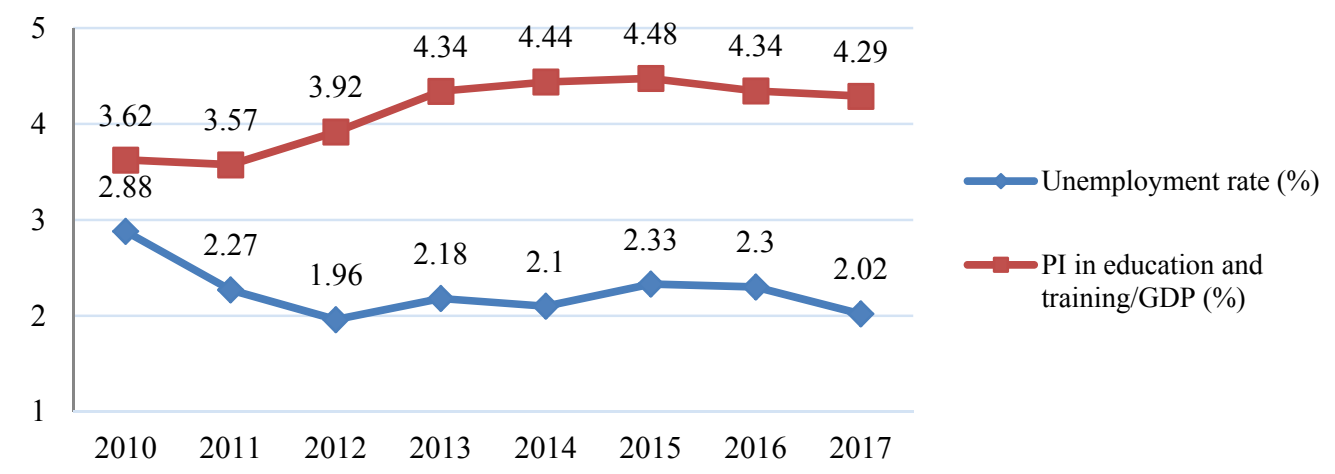

Figure 4. Unemployment rate and PI in education and training of Vietnam

Source: GOS (2016)

However, it is concerned that the labor force even trained cannot meet the requirement of the job. Even students graduated excellently from university are not appreciated and recruited. To the end of second quarter 2017, 
unemployed people graduated from university increased over 44 thousand people to 183 thousand ones (equivalent to $3.63 \%$ ). Long-term unemployed people (over 12 months) made up $24.5 \%$ of total unemployment. Besides, many training services are not sufficiently invested with infrastructure as well as teacher; it is difficult for these services to perform well in education and training.

\section{- Impact on poverty}

Similar to the relationship with unemployment rate, the ratio of poor household of Vietnam decreased when the public investment in education and training increased. By expanding investment in education and training, the people have chance to approach with new technology and science, and then develop business and production, increasing income, making contribution to eliminate hunger and reduce poverty sustainably. The ratio of poor household in the period 2015-2016 tended to increase. However, according to experts, it is because the government of Vietnam applied new criteria for poverty, with higher standard. To the year 2007, the poverty rate reduced to below $7 \%$ (1.3\% in comparison with the end of 2016).

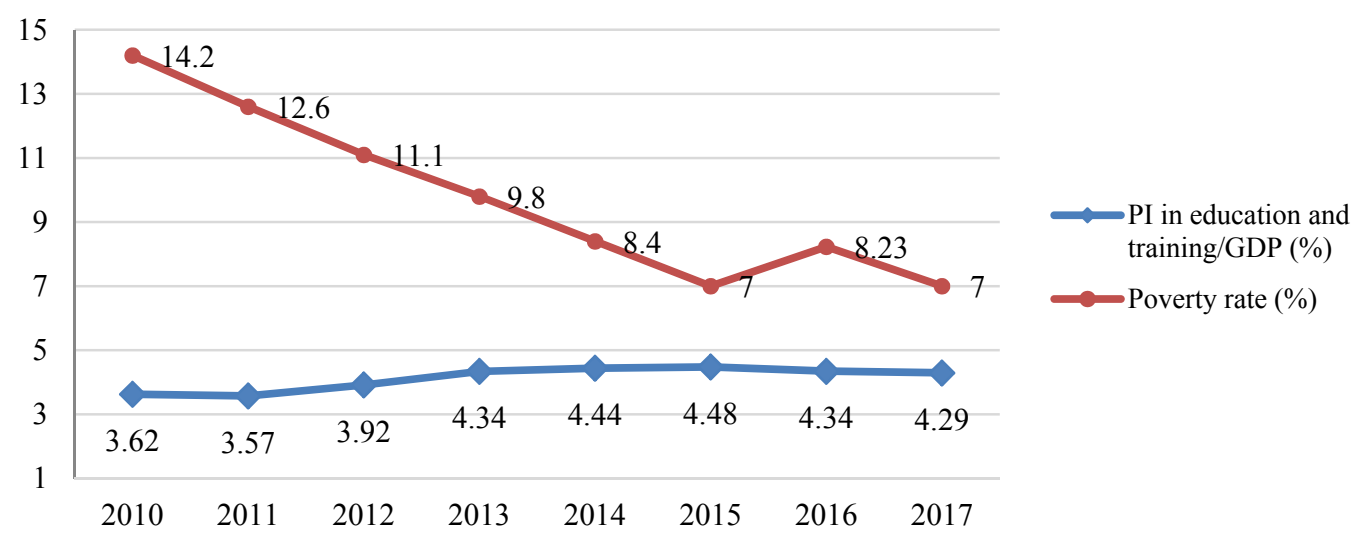

Figure 5. Poverty rate and PI in education and training of Vietnam

Source: GOS (2016)

In fact, the state decreed policies of investment in education and training to encourage people to go to school, improving knowledge, competence and working productivity, creating more property, making contribution to eliminate hunger and reduce poverty. Specifically, the government decreed policies to reduce and free charge of studying fee, building boarding-school in remote areas, creating conditions for the children to study, assigning teachers to remote areas to teach children in these places. Besides, the Party and the Government of Vietnam decreed flexible policies of education and training which are suitable with the goals of hunger elimination and poverty reduction for good. At the same time, the Government also invested in building new rural areas, developing infrastructure for education and training, building the road, creating the best condition for the people to study and develop.

\section{- $\quad$ Impact on income inequality}

Public investment in education and training has great effect on income inequality. It is clearly presented in recent years, when average income of $40 \%$ poorest households increased $9 \%$ per year. Living standard of people in rural areas is more and more improved. People were trained, improving their knowledge and working competence, and then their income increased. The people's living standard were clearly improved, children had right to go to school, and children do not leave school to work. 


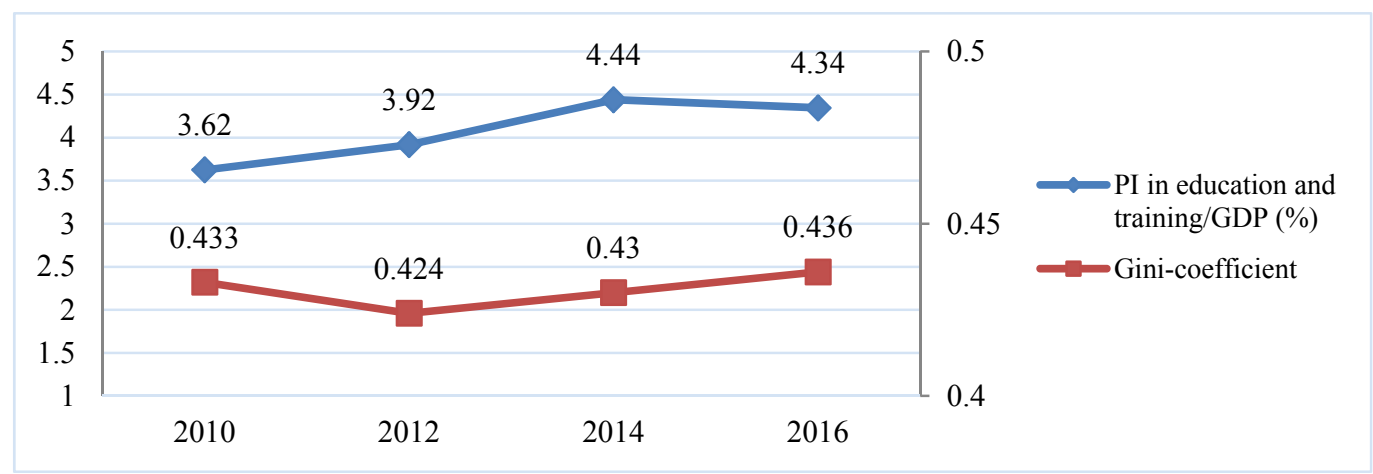

Figure 6: Gini-coefficient and PI in education and training of Vietnam

Source: GOS (2016)

However, the gap between groups of people in society tends to increased, which presented in the increasing Gini-coefficient in recent years. Vietnam's coefficient in 2010 was 0.43 ; it increased to 0.44 in 2016 . Besides, inequality between $20 \%$ of the richest and $20 \%$ of the poorest was 4.4 folds in 2010, increasing to 10 folds in 2016 . It is necessary for Vietnam to have suitable strategy to invest in education and training development, promoting working productivity, filling the gap between the rich and the poor, reducing Gini-coefficient.

\section{- Impact on intellectual level of people}

The large amount of investment in education and training has made contribution to improve knowledge and competence of Vietnamese people. By expending and upgrading infrastructure of education and training in rural areas and remote areas, the people have opportunities to approach with knowledge, improving their knowledge and competence. In direct ratio to the investment increase in education and training, the HDI of Vietnam was also gradually increased, which clearly presented the knowledge improvement of a country.

Table 1. HDI of Vietnam

\begin{tabular}{ccccc}
\hline Year & Life expectancy index & Education index & Income index & HDI \\
\hline 2010 & 0.84 & 0.48 & 0.38 & 0.572 \\
2011 & 0.85 & 0.48 & 0.38 & 0.593 \\
2012 & 0.85 & 0.51 & 0.38 & 0.617 \\
2013 & 0.86 & 0.51 & 0.59 & 0.638 \\
2014 & 0.86 & 0.58 & 0.67 & 0.666 \\
2015 & 0.84 & 0.48 & 0.38 & 0.572 \\
\hline
\end{tabular}

Source: GOS (2016).

The above table indicates that from 2010, longevity index of Vietnam evenly and sustainably increased; education and training index was also improved and strongly increased in 2015. Thus, the growth of HDI was significantly contributed by income index and education index.

\section{Implications of the Results}

Apart from achieved success, Vietnam's investment in education and training also has shortcomings such as unsuitable investment structure, unbalance structure of education and training, unreasonable budget allocation; the education and training have not linked to target, not basing on output efficiency. Thus, we propose some recommendation for improving the performance of public investment in education and training in Vietnam as follows:

Firstly, it is necessary to adjust structure for investment in education and training. Investment structure needs to efficiently attract, manage and use financial resource to develop the economy and society. At the same time, the government needs to invest in the areas with difficult condition, in remote area to create conditions to evenly develop the different locations. Besides, it is important to increase investment in development, reducing often expense. Also, it is necessary to focus on special subject or basic science education with short demand by society.

Secondly, investment in education and training needs to focus on demand and human resource development 
potential basing on career. In the present period, the state needs to invest in development of human resource with high demand such as IT engineers, electronic and electricity engineer, mechanical equipment, weaving and sewing...

However, to ensure meeting demand on human resource in the future, the state also needs to notice investment in training of some careers with development potential in the future, which are presently thirst for high quality labor and will have high demand in the future such as computer programmer, organic producer...

Thirdly, it is also necessary to focus on creating condition for private companies to join in this field, reduce the burden for state-owned companies. Accordingly, it is important to invest in main education and training, avoiding investing in different fields or services. The state should gradually increase studying fee from learners to compensate training expense to adjust the price, as Decree No. 16/2015/NĐ-CP of the government. The State only directly supports the study fee to several subjects, giving preferential loans to the poor students. At the same time, the state also needs to establish the policies to encourage private companies to invest in education and training, promoting education and training socialization, especially in the field of technique, technology and vocational school.

Fourthly, the government should simplify investment procedure. On the basis of ensuring the united regulation and the management of the state with education and training, the state needs to simplify the regulations of procedure and conditions to supply service of education and training, and at the same time, encouraging the competitiveness in education and training. This creates conditions to timely fund for educational services and agencies, especially in the remote areas.

Fifthly, it is important to establish and promulgate mechanism to investigate, to supervise and examine the investment in education and training. To ensure the efficiency of investment, avoiding corruption, the state needs to establish a ministry specializes in managing and investigating investment in education and training in all levels; at the same time, it also needs to improve quality and efficiency of administrative investigation and specialized investigation in schools and educational agencies, speeding up investigation and examination with educational activities, concentrating on the complicated complaint and negative phenomenon causing social urgent matter.

\section{Concluding Remarks}

Education and training has positive impacts and benefits for economy and society. Thus, almost countries spend a large amount of public budget for investment in education and training. In Vietnam, the government attached special importance to public investment in education and training. According to the General Statistics Office of Vietnam, public investment in education and training occupies approximately $20 \%$ of total public budget, equivalent to 5\% GDP. This rate is high in comparison with many countries in the world, even with developed countries. These investments promote economic growth by improving the quality of labor force and working conditions, by reducing poverty, and improving the intellectual level of the people

However, our analysis indicated that public investment in education and training of Vietnam has still some shortcomings such as unreasonable investment structure in education and training (unbalanced investment in different levels); unequal educational structure; not connect the education and training with the target; not base on output efficiency. Therefore, we propose some recommendations to improve the quality of public investment in education and training of Vietnam in the near future.

\section{References}

Becker, G. (2009), Human Capital: A Theoretical and Empirical Analysis, with Special Reference to Education (3rd ed.). University of Chicago Press.

Chiswick, B. (1974). Income Inequality: Regional Analyses Within a Human Capital Framework (1st ed.). National Bureau of Economic Research: distributed by Columbia University Press.

Ganegodage, K. R., \& Rambaldi, A. N. (2011). The impact of education investment on Sri Lankan economic growth. Economics of Education Review, 30(6), 1491-1502. https://doi.org/10.1016/j.econedurev.2011.08.001

GOS. (2016). Statistical yearbook of Vietnam 2016. General Statistics Office of Vietnam

Iatagan, M. (2015). Consequences of the Investment in Education as Regards Human Capital. Procedia Economics and Finance, 23, 362-370.

McCord, G. C., \& Sachs, J. D. (2013). Development, Structure, and Transformation: Some Evidence on Comparative Economic Growth. NBER Working Paper, No. 19512, National Bureau of Economic Research, Cambridge, MA. 
McGrath, S., \& Akoojee, S. (2009). Vocational education and training for sustainability in South Africa: The role of public and private provision. International Journal of Educational Development, 29(2), 149-156. https://doi.org/10.1016/j.ijedudev.2008.09.008

Mincer, J. (1974). Schooling, Experience, and Earnings (1st ed.). National Bureau of Economic Research.

Osberg, L., \& Sharpe, A. (2002). An Index of Economic Well-being for OECD Countries. Review of Income and Wealth, 48(3), 291-316. https://doi.org/10.1111/1475-4991.00056

Romer, P. M. (1994). The origins of endogenous growth. Journal of Economic Perspectives, 8(1), 3-22. https://doi.org/10.1257/jep.8.1.3

Sianesi, B., \& Van Reenen, J. (2003). The returns to education and training: Macroeconomics. Journal of Economic Surveys, 17(2), 157-200.

UNESCO. (2014). UNESCO Education and training Strategy 2014-2021. United Nations Education and training, Scientific and Cultural Organization.

\section{Copyrights}

Copyright for this article is retained by the author(s), with first publication rights granted to the journal.

This is an open-access article distributed under the terms and conditions of the Creative Commons Attribution license (http://creativecommons.org/licenses/by/4.0/). 